that respect no other industry in the country was so well served as the mines; experience was being gained by which the miners' rehabilitation service would be the forerunner of similar services for other industries in future years. The Chairman of the Miners' Welfare Commission, when opening yet another centre, forecast that by this summer the immediate requirements of practically the whole of the coal-mining industry would have been met by the provision of seven rehabilitation centres and six other centres at hospitals. ${ }^{1}$ This is an outstanding achievement. Mr. Will Lawther, President of the Mine Workers' Federation of Great Britain, said on the same occasion that the provision of such centres brought a new hope and a new outlook to men in industry. It was true that in the past both sides had been satisfied with the payment of compensation to the injured, but to-day both realized that there was a common duty to see that 'life began again' for those injured in Britain's premier industry.

\section{REHABILITATION TO COME}

In 1941 the Ministry of Labour started a scheme ${ }^{2}$ to help those who had been injured on active service, in air-raids, and in factories or elsewhere, to take -up employment suited to their disability and to help those with pre-war disablement to prove their capacity for useful work, so that they could play their part in the war effort. A further pronouncement has now come from the Ministry, ${ }^{3}$ consolidating the original scheme. That it is a forecast of things to come - and in particular of a widening of the meaning of rehabilitation-is indicated in the statement that 'the scheme provides, as an interim measure, facilities of the kind which will eventually be provided under the Disabled Persons (Employment) Act, 1944,'4 recently added to the Statute Book. This Act will always be associated with the name of Tomlinson who piloted the Bill so successfully through the House of Commons. It is the direct outcome of the work of his committee which published its comprehensive report on rehabilitation in 1943.5 The Minister of Production, Mr. Lyttelton, recently stated ${ }^{6}$ that the Home Secretary would be presenting a new Workmen's

\footnotetext{
1 Times, May 23, 1944. Persons. Ministry of Labour, Oct., 1941. PL 93/1941. Pp. 8 .
Training and Resettlement of Disabled Persons. Ministry of Labour, March, 1944. PL 93/1944 (revised). Pp. 10.

47 \& 8 Geo. 6. Ch. 10 .

5 Report of Inter-dept. Cttee. on Rehabilitation and Resettlement

of Disabled Persons, Jan., 1943, Cmd. 6415. H.M.S.O. Pp. 51

6 Times, May 1, 1944.
}

Compensation Bill to the House. ${ }^{1}$ This is of im portance to those who are responsible for treatment and rehabilitation, because, again, it is a portent of things to come. Compensation laws are intricate; they have much to do with the economics of rehabilitation and for that reason need careful study. A new and inexpensive publication-price 3d.- provides for this in brief and simple form. ${ }^{2}$

This legislative activity is of special interest to the medical officer in industry, in particular the Disabled Persons (Employment) Act. $^{3}$ The movement to help the disabled man and woman of this country is another sign of the growing recognition of medicine as a social service: the Act itself has been described as ' a first instalment towards social security.' 4 But there is still a further implication, one which will materially affect the future of industrial medicine. Many men will be returning from the Services to industry who will be physically and mentally disabled. These men are to be fitted into our industrial structure. The State has set up the machinery for this, but it will fall to the doctor working within industry to set it in motion. He is the one man who knows both the detail of the work to be done and the capacity of the worker to do it: and it will be his personal challenge, when the time comes, to ensure that he is not only fully informed but fully prepared.

\section{PAPER FOR THE JOURNAL}

The first number of this Journal was rapidly out of print, but a further allocation of paper enabled a second edition to be published. This has by no means met the increasing demand, and we regret that many individuals are unable to obtain their own copy. It has been suggested by a correspondent that copies of the Journal could be circulated locally between groups of people who are desirious of seeing it. As many medical libraries as possible have been supplied with copies. These arrangements, however, are not satisfactory, and as soon as more paper becomes available more copies will be printed. In the meantime a waiting list is being kept of those who wish to have the JournaL, and they will be notified as soon as their wish can be met. Names will be taken in strict rotation.

\footnotetext{
1 It has been reported that the White Paper embodying the Government's proposals for a new system of workmen's compensation will be published when Parliament re-assembles in September 1944 2 Memorandum on the Workmen's Compensation Acts, 1925 1943. Home Office, March, 1944. H.M.S.O. Pp. 18.

3 This Act defines a disabled person as " a person who, on accoun of injury, disease, or congenital deformity, is substantially handicapped in obtaining or keeping employment, or in undertaking work on his own account, of a kind which apart from that injury, disease or deformity would be suited to his age, experience, and qualifications." 4 Times, May 22, 1944 .
} 